\title{
Screening of Phytochemical Secondary Metabolites of Muntingia Calabura: a Potential as Hepatoprotector
}

\author{
Elasari Dwi Pratiwi* Niluh Puspita Dewi \\ ${ }^{1}$ School of Pharmacy, Faculty of Health Science, Universitas Muhammadiyah Lamongan, Jl Raya Plalangan Plosohwahyu KM 2 Lamongan, \\ Surabaya 62211 \\ ${ }^{2}$ School of Pharmacy, Sekolah Tinggi Ilmu Farmasi Pelita Mas Palu, Jl Wolter Monginsidi No. 106A, Palu 94236
}

\begin{abstract}
Muntingia calabura is one of the plants employed to produce herbalbased treatments. Muntingia calabura leaves are traditionally used as an alternative medicine due to their secondary metabolites. The maceration method extracted Muntingia calabura leaves using 96\% ethanol solvent for $3 \times 24$ hours. The fractionation process was carried out using a separating funnel method with different polarities, such as n-hexane, ethyl acetate, and ethanol-water. Thinlayer chromatography (TLC) was used to confirm the phytochemical screening. TLC conditions under UV light 254 and $366 \mathrm{~nm}$ using solvents, such as chloroform: methanol (alkaloids), butanol: acetic acid: water (flavonoids), chloroform:methanol: water (saponins), and chloroform: methanol (phenolic). The phytochemical screening results of extracts and Muntingia calabura fractions contained secondary metabolites, such as alkaloids, flavonoids, tannins, saponins, and phenolics. TLC results showed that $n$-hexane fraction contained flavonoid and saponin compounds; ethyl acetate fraction contained alkaloids, flavonoids, saponins and phenolic compounds; and ethanol-water fraction contained alkaloids, flavonoids, saponins, and phenolics. Muntingia calabura leaves indicated the potential as herbal medicine by containing secondary metabolites.
\end{abstract}

\section{Data of article}

Received : 21 July 2021

Reviewed : 26 Aug 2021

Accepted : 13 Jan 2022

DOI

10.18196/jfaps.v2i1.12364

Type of article:

Research

Keywords: Fractionation; Muntingia Calabura; Phytochemical Screening; TLC

\section{INTRODUCTION}

Natural resources have benefits for various purposes, such as developing herbalbased medicines ${ }^{1}$. The utilization of natural ingredients for traditional medicine has been consumed by a large number of people in the world for many years ${ }^{2}$. In addition, traditional medicine is also used as a health supplement by $80 \%$ of the population in developing countries around the world, and about $85 \%$ of ingredients in traditional medicine involve plant extracts 3 . One of the plants used as traditional medicine is Muntingia calabura.

Muntingia calabura belongs to the Elaeocarpaceae family, widely used in traditional medicine. People in Indonesia usually eat the fruit directly due to its sweet taste 4 . Meanwhile, the Peruvian people have used the flowers and stem as an antiseptic to reduce swelling of the prostate gland and reduce headaches and fever ${ }^{5}$. Several studies have shown that extracts of Muntingia calabura had a

*Corresponding author, e-mail: edpratiwi8@gmail.com 
variety of activities that had been tested, such as antioxidant ${ }^{6}$, anticancer ${ }^{7}$, antidiabetic ${ }^{8}$, antibacterial9, and antiinflammatory ${ }^{10}$.

Based on this information, this study aims to determine the secondary metabolites contained in the Muntingia calabura leaf fraction so that further tests can be carried out both in vivo and in vitro as hepatoprotection.

\section{METHOD}

This study is a laboratory experiment aiming to discover the secondary metabolites found in Muntingia calabura plants. This study was conducted at the Pelita Mas Palu School of Pharmacy's Phytochemical Laboratory.

\section{Research Tools and Materials}

The tools used in this study were an oven (Memmert Universal), rotary evaporator (Ryela N-100), water bath (Eyela SB-1000), TLC plate, Photometer 5010 (RieleGermany), UV lamp, and glassware (pyrex).

The materials used in this study were Muntingia calabura leave, ammonia (Merck), aquadest, anhydrous acetic acid (Merck), $\mathrm{HCl}$ (Merck), concentrated $\mathrm{HCl}$ (Merck), $\mathrm{H}_{2} \mathrm{SO}_{4}$ (Merck), butanol (Merck), ethanol 96\% (Merck), ethyl acetate (Bratachem), $\mathrm{FeCl}_{3}$ (Merck), chloroform (Merck), methanol (Merck), $\mathrm{NaCl}$ (Merck), n-hexane (Merck), ragendroff Merck), magnesium powder $\mathrm{P}$ (Merck).

\section{Determination}

The identification of Muntingia calabura was carried out at UPT. Biological Resources Tadulako University, Central Sulawesi.

\section{Preparation of Muntingia calabura Extracts and Fractions}

The maceration method extracted Muntingia calabura Simplicia using 96 percent ethanol solvent for $3 \times 24$ hours. To obtain a thick Muntingia calabura extract, the maceration results were filtered and concentrated using a rotary evaporator at a temperature of $40-50^{\circ} \mathrm{C}^{11}$.

The thick ethanol extract of Muuntingia calabura leaves was fractionated using non-polar, semi-polar and polar solvents (n-hexane, ethyl acetate and water). First, the thick Muntingia calabura extract was fractionated in a separating funnel with $\mathrm{n}$ hexane and water (1:3) and thoroughly shaken. After that, it was left until two layers, the $\mathrm{n}$-Hexane layer and the water layer had formed. To get the n-hexane fraction, the process was repeated three times. The water layer was fractionated three times with ethyl acetate (3:1), yielding the water and ethyl acetate fractions. To obtain a thick fraction of Muntingia calabura leaves, the results of the $\mathrm{n}$-hexane and ethyl acetate fractions were condensed with a rotary evaporator at a temperature of $40-50^{\circ} \mathrm{C}^{11}$.

\section{Phytochemical Screening of Muntingia calabura Extract and Fraction}

\section{Alkaloids Test}

0.5 grams of the extract was weighed, and the thick fraction of Muntingia calabura leaves were weighed and placed in an Erlenmeyer with $5 \mathrm{ml}$ chloroform and $5 \mathrm{ml}$ ammonia. It was then heated on a water bath, shaken and filtered. 5 drops of $2 \mathrm{~N}$ $\mathrm{H}_{2} \mathrm{SO}_{4}$ were added to the filtrate in a test tube. Dragendorff's reagent was added to each tube containing the filtrate, along with several $\mathrm{mL}$ of $\mathrm{HCl}$, and the tubes were filtered. Dragendorff's reagent produced red-orange precipitation, which indicated a positive reaction ${ }^{12}$. 


\section{Flavonoids Test}

0.5 grams of the extract was weighed, and the thick fraction of Muntingia calabura leaves was added with $10 \mathrm{ml}$ of distilled water and heated for 1 minute on a water bath. It was then filtered and dissolved in 1 $\mathrm{ml}$ of ethanol (95\%) with magnesium $\mathrm{P}$ powder. If a crimson hue appeared after being dissolved in $10 \mathrm{~mL}$ of strong hydrochloric acid, it would indicate the presence of flavonoids ${ }^{12}$.

\section{Saponins Test}

0.5 grams of the extract was weighed, and a fraction of Muntingia calabura leaves were put into a test tube. After that, the 10 $\mathrm{mL}$ of hot water was added, let cool, and was shaken vigorously for 10 seconds. Saponins would be present if a foam formed and lasted for at least 1 minute at the height of $10 \mathrm{~cm}$ or if 1 drop of $2 \mathrm{~N}$ hydrochloric acid did not evaporate after being added ${ }^{12}$.

\section{Tannins Test}

0.5 grams of extract and a thick fraction of Muntingia calabura leaves were weighed and placed in a test tube with $20 \mathrm{~mL}$ hot water and 3 drops of a $10 \% \mathrm{NaCl}$ solution. If a blue-black color appeared after adding a $\mathrm{FeCl}_{3}$ solution, it would mean the presence of tannin ${ }^{12}$.

\section{Phenolic Test}

0.5 grams of extract and a thick fraction of Muntingia calabura leaves were weighed and dissolved in $5 \mathrm{~mL}$ of water. If a dark green color shift occurred after adding a few drops of $5 \% \mathrm{FeCl}_{3}$ solution, it would mean the existence of phenolic ${ }^{12}$.

\section{Thin-Layer Chromatography of Qualitative Test}

\section{Alkaloids Test}

In the development of chloroform: methanol (85:15), the sample was detected on a silica gel plate. Detection of the presence of alkaloids was conducted under UV light 254-366 nm. Ensure that the plate was sprayed with Dragendorff's reagent, and spots would appear if it were positive for alkaloids ${ }^{13}$.

\section{Flavonoids Test}

In the development of butanol: acetic acid: water (4:1:5), the sample was detected on a silica gel plate. Detection of the presence of flavonoids was conducted under UV light 254-366 nm. It was then sprayed with $\mathrm{AlCl}_{3}$ staining solution in chloroform; yellow color indicated the presence of flavonoids ${ }^{13}$.

\section{Saponins Test}

The sample was detected on a silica gel plate in developing chloroform: methanol: water (40:50:10). It was then sprayed with a mixture of anisaldehyde and sulfuric acid reagent, which produced a purplish-blue tint with a hint of yellow ${ }^{13}$.

\section{Phenolic Test}

In the development of chloroform: methanol (9:1), the sample was detected on a silica gel plate. It was then sprayed with $\mathrm{FeCl}_{3}$ reagent and formed a blackish blue, green or turquoise color ${ }^{13}$.

\section{RESULTS AND DISCUSSION}

The test material in this study was Muntingia calabura leaves obtained from the city of Palu and was started from June to August 2020. The determination aimed to determine the accuracy of the test material employed. Determination of Muntingia calabura leaves was carried out at UPT. Biological Resources Tadulako University, Central Sulawesi. The analysis revealed that the Muntingia calabura leaves utilized in the study belonged to the genus Elaeocarpaceae.

Muntingia calabura leaves were made by maceration using ethanol as a solvent ${ }^{14}$. 
62 Elasari Dwi Pratiwi \& Niluh Puspita Dewi| Screening of Phytochemical Secondary Metabolites of Muntingia Calabura:

The thick extract of Muntingia calabura leaves obtained from the simplicia maceration was 45 grams with a yield value of $6.4 \%$. Furthermore, the thick extract of Muntingia calabura leaves was fractionated using 3 solvents, namely $n$ hexane, ethyl acetate and ethanol-water. The weight of each fraction obtained was the $\mathrm{n}$-hexane fraction of Muntingia calabura leaves of 20.29 grams with a yield value of $4.05 \%$, the ethyl acetate fraction of Muntingia calabura leaves of 13.91 grams with a yield value of $2.7 \%$ and the ethanol-water fraction of Muntingia calabura leaves of 29.17 grams with a yield value of $5.83 \%$.

The class of secondary metabolites found in Muntingia calabura leaves extract as bioactive chemicals expected to have a role in delivering hepatoprotective effects was determined through phytochemical testing. The ethanol extract of Muntingia calabura leaves contained positive alkaloids, flavonoids, saponins, tannins, and phenolics, according to the results of phytochemical screening (Table I).

Table 1. The Results of Phytochemical Screening of Muntingia calabura Extract

\begin{tabular}{llll}
\hline Chemical Compounds & Reagent & Result & Exp. \\
\hline Alkaloids & Dragendorf & Red & $(+)$ \\
\hline Flavonoids & Mg powder $+\mathrm{HCl}$ & Red yellow & $(+)$ \\
\hline Saponins & Water $+\mathrm{HCl}$ & Foam $\pm 1 \mathrm{~cm}$ & $(+)$ \\
\hline Tannins & $\mathrm{FeCl}_{3}+\mathrm{NaCl} 10 \%$ & Blackish green & $(+)$ \\
\hline Phenolic & $\mathrm{FeCl}_{3} 1 \%$ & Blackish green & $(+)$ \\
\hline
\end{tabular}

Note: $(+)$ : Detected

$(-)$ : Not detected

As Muntingia calabura leaves extract contained a wide range of polar, semipolar, and non-polar secondary metabolite chemicals, the fractionation method was used to separate some of these compounds based on their polarity. Fractionation was carried out in stages, starting with separating non-polar compounds using n-hexane as a non-polar solvent, then semi-polar compounds using ethyl acetate as a semi-polar solvent, and finally using water as a polar solvent to attract polar compounds ${ }^{15}$. The phytochemical screening of the obtained fractions revealed that alkaloids, flavonoids, saponins, tannins, and polyphenols were present in the Muntingia calabura fractions (Table 2).

Table 2. The Results of Phytochemical Screening of Muntingia calabura Fractionation

\begin{tabular}{llccc}
\hline \multirow{2}{*}{ Chemical Compound } & Reagent & $\begin{array}{l}\text { Result } \\
\text { n-Hexane } \\
\text { Fraction }\end{array}$ & $\begin{array}{l}\text { Ethyl } \\
\text { Fraction }\end{array}$ & $\begin{array}{l}\text { Acetate } \\
\text { Ethanol-Water } \\
\text { Fraction }\end{array}$ \\
\hline Alkaloids & Dragendorf & - & + & + \\
Flavonoids & $\mathrm{Mg}$ and $\mathrm{HCl}$ & + & + & + \\
Saponins & Water and HCl & + & + & + \\
Tannins & $\mathrm{FeCl}_{3}+\mathrm{NaCl}$ & - & + & + \\
Phenolic & $\mathrm{FeCl}_{3}$ & - & + & + \\
\hline
\end{tabular}

Note: (+) : Detected

$(-)$ : Not detected

Thin-layer chromatography (TLC) was performed to observe the chromatogram pattern of the Muntingia calabura fraction. TLC can be identified by separating the 
Muntingia calabura fraction and the elvent. The elvents used in determining the chromatogram of the Muntingia calabura fraction were alkaloid compounds using a mixture of chloroform: methanol (85:15), flavonoid compounds using a mixture of butanol: acetic acid: water (4:1: 5), saponin compounds using a mixture of chloroform: methanol: water (40:50:10) and phenolic compounds using a mixture of chloroform: ethanol ( $9: 1)$. The observations were conducted under UV light 254 and $366 \mathrm{~nm}$. At UV $254 \mathrm{~nm}$, the plate fluoresced while the sample appeared dark in color. Meanwhile, the stain fluoresced at UV $366 \mathrm{~nm}$, and the plate appeared dark in color. It was then followed by spraying using $10 \% \mathrm{H}_{2} \mathrm{SO}_{4}$ in methanol. The results of TLC showed that the Muntingia calabura fraction contained alkaloids, flavonoids, saponins and phenols, which were indicated by purple spots (Table 3 and figure 1 ).

Table 3. The Results of Thin-Layer Chromatography

\begin{tabular}{lllll}
\hline $\begin{array}{l}\text { Chemical } \\
\text { Compound }\end{array}$ & Eluent & $\begin{array}{l}\text { n-Hexane } \\
\text { Fraction }\end{array}$ & $\begin{array}{l}\text { Ethyl Acetate } \\
\text { Fraction }\end{array}$ & $\begin{array}{l}\text { Ethanol-Water } \\
\text { Fraction }\end{array}$ \\
\hline Alkaloids & $\begin{array}{l}\text { Chloroform: Methanol } \\
(85: 15)\end{array}$ & - & + & - \\
\hline Flavonoids & $\begin{array}{l}\text { Butanol:Acetic acid:Water }(4: 1 \\
: 5)\end{array}$ & + & + & + \\
\hline Saponins & $\begin{array}{l}\text { Chloroform:Methanol:Water } \\
(40: 50: 10)\end{array}$ & + & + & + \\
\hline Phenolic & $\begin{array}{l}\text { Chloroform: Methanol } \\
(9: 1)\end{array}$ & - & + & + \\
\hline
\end{tabular}

Note: $(+)$ : Detected

$(-)$ : Not detected
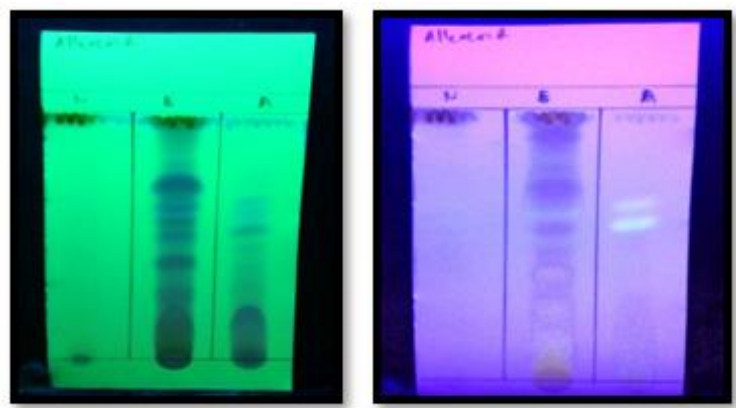

(a)
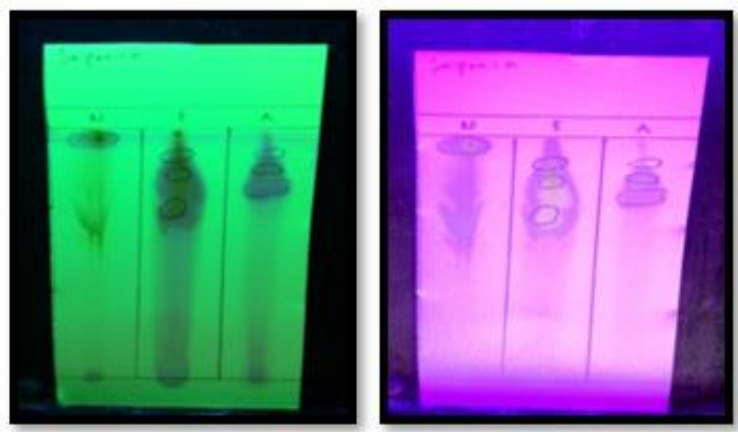

(c)
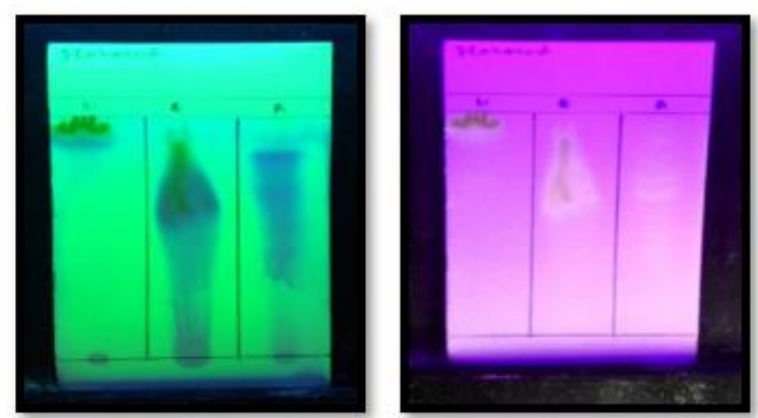

(b)
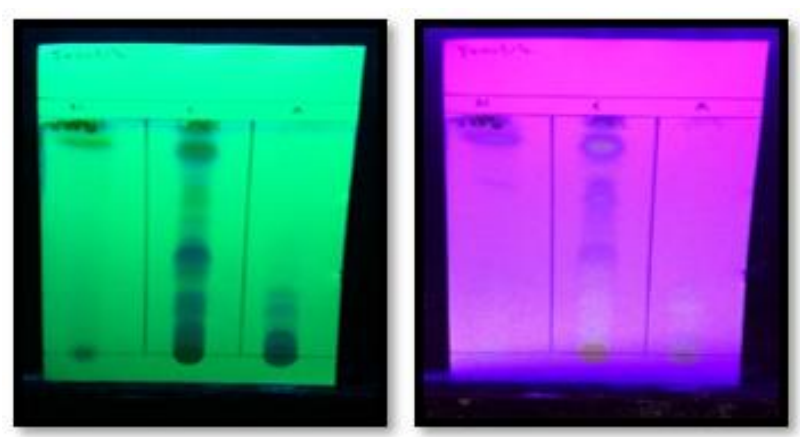

(d)

Figure 1. Thin-layer chromatography test using UV light with a wavelength of $254 \mathrm{~nm}$ and $366 \mathrm{~nm}$ (a) Alkaloids; (b) Flavonoids; (c) Saponins; (d) Phenolic 
64 Elasari Dwi Pratiwi \& Niluh Puspita Dewi | Screening of Phytochemical Secondary Metabolites of Muntingia Calabura: a Potential as Hepatoprotector

The result of TLC profiling is summarized in figure 1. N-hexane fraction Muntingia calabura showed the presence of flavonoid (Rf o.8) and saponin (Rf o.8). Ethyl acetate fraction Muntingia calabura showed the presence of alkaloid ( $R f 0.7$ ), flavonoid ( $R f$ o.6), saponin (Rfo.8) and phenolic (Rf o.8). Ethanol-water fraction Muntingia calabura showed the presence of flavonoid (Rf 0.5 ), saponin (Rf 0.7), and phenolic (Rf 0.3). TLC is usually done for better identification of the bioactive compounds. Different Rf values of the compounds provide an idea about their polartity that may also help select a particular solvent system to isolate any compound from the plant fraction further using chromatographic and spectroscopic. Compounds with a high $\mathrm{Rf}$ value in a less polar solvent system have low polarity while those with a low Rf value have high.

These findings suggested that Muntingia calabura fractions could be evaluated in vivo and in vitro for hepatoprotective properties. Research conducted by (Haki, 2019) revealed that the Muntingia calabura extract could reduce the ALT enzyme of mice although it had not reached the normal value ${ }^{16}$. Furthermore, (Hakim, 2012) research stated that the Muntingia calabura extract dose of $420 \mathrm{mg} / 200 \mathrm{gram}$ and $84 \mathrm{mg} / 200$ gram could prevent increased levels of the enzyme ALT in acetaminophen-induced rats ${ }^{17}$. This information is critical for a simple standardization in evaluating activity as herbal-based medicines.

\section{CONCLUSION}

Based on the research results, it is confirmed that Muntingia calabura contained alkaloids, tannins, saponins, and phenolics, as evidenced by TLC results. As a result, Muntingia calabura played hepatoprotective herbal components that could be investigated in vivo and in vitro.

\section{REFERENCES}

1. Gurning, K., \& Simanjutak, H. A. Karakteristik dan Skrining Fitokimia Daun Pirdot (Saurauia vulcani Korth.). Eksakta: Jurnal Penelitian dan Pembelajaran MIPA. 2020;5(2):98105.

http://dx.doi.org/10.31604/eksakta.v5 i2.98-105

2. Maqbool, M., Dar, M. A., Gani, I., Mir, S. A., \& Khan, M. Herbal Medicines as An Alternative Source og Therapy : A Review. World Journal of Pharmacy and Pharmaceutical Science. 2019;3(2):374-380.

3. Putri, D. A, \& Fatmawati, S. Metabolit Sekunder dari Muntingia calabura dan Bioaktivitasnya. Alchemy Jurnal Penelitian Kimia. 2019;5(1):57-78. https://doi.org/10.20961/alchemy.15.

\section{$1.23362 .57-78$}

4. Mahmood, N. D., Nasir, N. L. M., Rofiee, M. S., Tohid, S. F. M., Ching, S. M., Teh, L. K., Salleh, M. Z., \& Zakaria, Z. A. Muntingia calabura: A review of its traditional uses, chemical properties, and pharmacological observations. Pharmaceutical Biology. 2014:52(12),1598-1623.

https://doi.org/10.3109/13880209.201 4.908397

5. Sufian, A. S, Ramasamy, K., Ahmat, N., Zakaria, Z. A., Izwan, M., \& Yusof, M. Isolation and identification of antibacterial and cytotoxic compounds from the leaves of Muntingia calabura L. Journal of Ethnopharmacology 2013:146,198-204. 
https://doi.org/10.1016/j.jep.2012.12. 032

6. Buhian, W. P. C., Rubio, R. O., Valle, D. L. J., \& Puzon, J. J. M. Bioactive metabolite profiles and antimicrobial activity of ethanolic extracts from Muntingia calabura L. leaves and stems. Asian Pacific Journal of Tropical Biomedicine. 2016:6(8), 682-685. https://dx.doi.org/10.1016/j.apjtb.201 $\underline{6.06 .006}$

7. Rofiee, M. S., Yusof, M. I. M., Hisam, E. E. A., Bannur, Z., Zakaria, Z. A., Somchit, M. N., Teh, L. K., and Salleh, M. Z. Isolating the metabolic pathways involved in the hepatoprotective effect of Muntingia calabura against $\mathrm{CCl}_{4}$ induced liver injury using LCMS QTOF. Journal of Ethnopharmacology. 2015:166,109-118.

https://doi.org/10.1016/j.jep.2015.03.016

8. Gurning, K., \& Sinaga, H. In Vitro AntiDiabetic Potential Extract Tesy of Sei (Muntingia calabura L.) Leaves. Asian Journal of Pharmaceutical Research and Develpoment. 2020;8(6):117-122. https://dx.doi.org/10.22270/ajprd.v8i $\underline{6.874}$

9. Rajesh, R., Jaivel, N., \& Marimuthu, P. Antifungal metabolite from Muntingia calabura root against early leaf blight of tomato. Journal of Medicinal Plant Research. 2014:8(17), 646-656.

10. Balan, T., Sani, M. H. M., Ahmad, S. H. M., Suppaiah, V., Mohtarrudin, N., Jamaludin, F., and Zakaria, Z. A. Antioxidant and anti-inflammatory activities contribute to the prophylactic effect of semi-purified fractions obtained from the crude methanol extract of Muntingia calabura leaves against gastric ulceration in rats. Journal of Ethnopharmacology. 2015:164, 1-15. https://doi.org/10.20961/alchemy.15. 1.23362.57-78

11. BPOM. Pedoman Pelaksanaan Uji Klinik Obat Tradisional. Departemen Kesehatan Republik Indonesia, Direktorat Pengawasan Obat Tradisional, Jakarta. 2010.

12. Bambang, S. Materia Medika Indonesia. Jilid VI. Direktorat Jenderal Pengawasan Obat dan Makanan. 1995. 21p.

13. Wagner, H. Zgainsi, E. M. Plants Drug Analysis. New York: Springer Veriag Berlin Heidelberg. 188-189p.

14. Vifta, R. L., Advistasari, Y. D. Skrinning Fiotikimia, Karakteristik, dan Penentuan Kadar Flavonoid Total Ekstrak dan Fraksi-Fraksi Buah Parijoto (Medinilla speciosa B.). Prosiding Seminar Nasional Unimus.2018;1:8-14.

15. Harbone, J.B. 1987. Metode Fitokimia. Diterjemahkan oleh Sujatmi. Bandung. ITB Perss.

16. Haki, M. 2009. Efek Ekstrak Daun Talok (Muntingia calabura L.) Terhadap Aktivitas SGPT Pada Mencit yang Diinduksi Karbon Tetraklorida. Skripsi. Fakultas Kedokteran Universitas Sebelas Maret. Surakarta.

17. Hakim, W. R. 2012. Uji Efek Daun kersen (Muntingia calabura L.) Terhadap kadar Alanin Aminotransferase (ALT) Pada Tikus Yang Diinduksi Asetaminofen. Fakultas kedokteran. Universitas Muhammadiyah

Surakarta. p. 12. 